\title{
Measuring the impact of knowledge sourcing and cooperation on innovation success: some empirical evidence from Turkey
}

\section{Clémentine Fry}

INFPC - Observatoire de la Formation, 12-14 Avenue Emile Reuter, L-2420 Luxembourg, Luxembourg Email: clementine.fry@infpc.lu

\author{
Anne-Laure Mention \\ Luxembourg Institute of Science and Technology, \\ Avenue des Hauts-Fourneaux, Belval, Luxembourg \\ and \\ School of Management (HEC), \\ University of Liege, Belgium \\ and \\ Tampere University of Technology, \\ 33720 Tampere, Finland \\ Email: anne-laure.mention@list.lu
}

\section{Serdal Temel*}

Ege University Department of Innovation and Entrepreneurship, Ege University Science and Technology Centre, 35100 Bornova, Izmir, Turkey Email: serdal.temel@ege.edu.tr *Corresponding author

\section{Marko Torkkeli}

Lappeenranta University of Technology, Prikaatintie 9, FI-45100 Kouvola, Finland Email: marko.torkkeli@lut.fi

\begin{abstract}
Innovation rarely occurs in isolation, and firms increasingly exploit cooperation strategies to increase their innovation propensity and performance. Empirical research concentrating on the breadth of cooperation practices, as well as the variety of objectives pursued in the context of innovation strategies remains scarce, and even more so for emerging economies. This paper aims to contribute to this literature stream by providing empirical evidence on the impact of the breadth of cooperation and innovation goals on innovation performance in Turkey. Results show that having six types of cooperation leads to the highest marginal effects on the innovation success while the probability to innovate is more determined by the objectives pursued rather than by cooperation itself.
\end{abstract}


Keywords: external information sourcing; breadth of innovation; emerging economy; probit/Tobit; CIS data; innovation propensity; Turkey; innovation performance.

Reference to this paper should be made as follows: Fry, C., Mention, A-L., Temel, S. and Torkkeli, M. (2016) 'Measuring the impact of knowledge sourcing and cooperation on innovation success: some empirical evidence from Turkey', Int. J. Transitions and Innovation Systems, Vol. 5, No. 1, pp.46-65.

Biographical notes: Clémentine Fry holds a Research Fellow position at vocational training observatory in Luxembourg (Institut national pour le développement de la formation professionnelle continue). After gaining eight years of professional experience in public and private research, she has worked for CRP Henri Tudor in October 2010-2015. As a Statistician for Parisian hospitals, she was involved in research on quality of life in nursing. Additionally, she previously worked as a Biostatistician/Data Manager for a clinical research organisation.

Anne-Laure Mention is holding an expert position in the field of innovation economics and management within the Luxembourg Institute of Science and Technology, Luxembourg. She is actively involved in research projects, mainly focusing on innovation and performance measurement and management in the financial and business to business services industries. Her research interests mainly concentrate on open and collaborative innovation, intellectual capital measurement and management, innovation and technology management. She has been a Visiting Researcher at Singapore Management University, McGill University, Canada and Ferrara University, Italy. She is the Deputy Head of the Centre for Performance Evaluation at HEC-Liege, a Visiting Professor at University of Liège and is a visiting faculty member at Tampere University of Technology. She received an IBM faculty award for the project entitled 'Towards accrued transparency of operations in the fund industry' in 2011 focusing on organisational innovation and an award for the project entitled 'Measuring the impact of open innovation' in 2013. She is also a founding member of WICI, the Deputy Head of the ISPIM advisory board and is a member of several scientific committees and editorial boards.

Serdal Temel is currently the Head of Innovation and Entrepreneurship Department of Ege University. He is also working as a researcher at Ege University Science Technology Center since 2000 and is responsible for university-industry cooperation, technology transfer, R\&D and innovation projects. Established by the IRC network, this centre was chosen as the most successful technology transfer office in the network by the EU Commission and Ege University Technology Transfer Office (EBILLTEM-TTO) in 2013. In addition, he has two book chapters published by McGraw-Hill, over 20 articles and on innovation, $\mathrm{R} \& \mathrm{D}$, and university-industry collaboration published in the International Journal of Innovation Science (IJIS), Journal of Technology Management \& Innovation (JOTMI), International Journal of Innovation Management (IJIM) and The International Journal of Entrepreneurship and Innovation (IJEI). In addition to current tasks, he is the Vice-Editor of the Journal of Entrepreneurship and Innovation Management (JEIM). 
Marko Torkkeli is a Professor of Technology and Business Innovations at the Lappeenranta University of Technology in Kouvola, Finland. His research interests focus on technology and innovation management, strategic entrepreneurship, growth venturing, and decision support systems. He has published in journals such as the Int. J. Production Economics, Int. J. Foresight and Innovation Policy, Int. J. Business Excellence, Int. J. Technology Management and Int. J. Technology Intelligence and Planning. He is a member of the editorial boards of the Int. J. of Services Sciences and the Int. J. of Innovation Management. He is an affiliated faculty member at Singapore Management University, a Visiting Researcher at INESC Porto, Portugal, Docent of Technology-Based Business at University of Jyväskylä, Finland and Docent of Technology and Innovation Management at Helsinki University of Technology, Finland. He serves as the Director of Publications of the International Society for Professional Innovation Management (ISPIM).

This paper is a revised and expanded version of a paper entitled 'External knowledge sourcing in Turkey: some empirical evidence' presented at ISPIM Asia-Pacific Innovation Forum, Singapore, 7-10 December 2014.

\section{Introduction}

Innovation is a risky economic endeavour. Companies start with promising ideas for innovation under conditions of high uncertainty, increased complexity and market volatility. As literature reports, only a few of those deliver successful results, taking the form of new products and services, which ultimately can have a positive impact on companies' growth (Porter, 1993; Enkel and Heil, 2014). Finding and developing new ideas for innovation projects are the most important steps in the innovation process and thus companies are trying to expand their horizons in their search for innovative ideas. For this purpose, cooperation with external partners has proven to be a good solution (Bamford et al., 2003; Chesbrough, 2003; Teece et al., 1997; Tidd, 2001). Many scholars have emphasised the value of external knowledge sourcing by exploiting external networks in the innovation process (Caloghirou et al., 2004; Cohen and Levinthal, 1990; George et al., 2002; von Hippel, 1988).

In the traditional innovation model, industry's main argument is that, for innovation to be successful, it needs to be fully controlled in order to bring about innovative products that contribute to the strategic goals of the company. Innovation is often regarded as something difficult to predict and even more difficult to manage. It is about searching into technological regimes that are more distant than current ones. This requires creativity and experimentation and developing knowledge-skills and capabilities that are new to most companies. If these activities are not well governed, they may drift away from the strategic goals of the company, and the organisation may develop the wrong knowledge, skills, and capabilities that ultimately do not contribute to company growth, resulting in a low return on investment.

The proposed and popularised model of innovation management is based on the need for companies to open up their innovation process, so as to collaborate with external partners such as suppliers, consumers, users, universities, research centres, and even competitors to develop innovations and to ultimately increase business performance (Alcalde and Guerrero, 2016; Löfsten, 2014; Mention, 2011). This new innovation 
paradigm was further stressed in the open innovation literature, by Chesbrough (2003), and has received huge interest from both academia and industry. According to Chesbrough (2003), internal $R \& D$ and innovation activities alone no longer constitute the right strategy, due to a fundamental change in companies' new idea generation process. Chesbrough (2003) depicts open innovation as "a paradigm that assumes that companies can and should use external ideas as well as internal ones, and internal and external paths to market, as the company seeks to advance their technology".

In this study, we advocate that the traditional closed innovation model is outdated and thus aim to contribute to the empirical literature in relation to the impact that the breadth and the openness of the innovation process has on companies. For the empirical analysis, we extend the exploration of breadth of innovation, as introduced by Leiponen and Helfat (2010).

This paper is structured as follows: the next section develops a number of hypotheses based on a review of innovation objectives, cooperation, open innovation, and breadth of innovation. The third section analyses the CIS dataset and variables, and Section 4 discusses the empirical findings. In the last section, we draw conclusions and highlight policy recommendations and managerial implications.

\section{Literature review and hypotheses development}

\subsection{Breadth of innovation}

Innovation is risky, and only a few innovators can expect to bring successful new goods and services to market. Only one project is successful out of 300 submitted ideas (Schilling, 2005). However, companies often search for knowledge and ideas through a very limited window (Helfat, 1994). Therefore, in order to increase the success rate of innovation projects for new and better products, it is very important to extend the breadth of the sources and objectives of innovation.

Most of the time, innovation objectives are focused on niches, product quality, services and scope. For large companies, it is easier to enter new markets or open up new markets with innovation activities. New technical possibilities and extended product range are the primary objectives of all companies deploying innovation projects. Beside the development of radical novelties, many companies pursue the objective of widening and extending current product and service offerings, through the implementation of innovation activities, as well as extending their current market share and even entering new markets. Cooper and Edgett (2003) have recognised new product development as one of the critical factors for successful innovation.

The main idea behind the shift from the traditional innovation paradigm to the open innovation paradigm is a change in the way of seeking new ideas for innovation. However, the use of different knowledge sources by a single company is generally shaped by the ecosystem, which includes new opportunities, level of economic turmoil and search skills of other companies (Cohen and Levinthal, 1990; Klevorick et al., 1995).

Those companies that invest in a broader and deeper search for new ideas may have a higher chance of changing and innovating (Laursen and Salter, 2006). Katila and Ahuja (2002) defined breadth as the number of different search channels that a company uses for innovation activities. Searching for innovative ideas is not just looking into a very high number of sources; but it is about focusing on key sources that might provide added 
value. The main sources for innovators are mainly lead users, suppliers and universities (Urban and von Hippel, 1988). In addition, universities, competitors, customers, and research centres are some of the main partners in idea generation. While universities and research centres play a key role in more radical or new-to-the-market innovation, (Kaufmann and Tödtling, 2001; Becker and Dietz, 2004), competitors and customers are used more for process and incremental product innovation.

Several researchers have discussed that, together with focusing on current types of innovation, companies also should pay attention to diversifying innovation (Forsman and Temel, 2011). For example, de Jong and Marsili (2006), Amara et al. (2009), Forsman and Annala (2011) and Damanpour et al. (2009) suggest that the diversity of innovation types increases, especially if a company is in active collaboration with different partners and sectors. Moreover, Leiponen and Helfat (2010) state that greater breadth of innovation objectives and knowledge sources is linked to greater innovation success at the company level, particularly on sales revenue from new products.

In the innovation process, the number of new ideas is important. However, the search for innovative ideas is not without cost and can turn out to be resource-demanding and time consuming. Therefore extending the breadth of searching for new ideas needs to be well analysed and carefully implemented.

\subsection{Innovation objectives and cooperation}

The broad definition of innovation as the successful exploitation of new ideas leads us to consider two common typologies that have been used to explore the links between the types of innovation and business success. Innovation was defined by Schumpeter (1934) as new or improved products, production techniques, organisation structures, discovery of new markets and the input of new factors. Schumpeter's ideas have stimulated researchers to develop innovation typologies resting on two common criteria: the degree of novelty and the degree of differentiation. On the other hand, Griliches (1994) describes innovation as the product of knowledge generating inputs. The literature abounds on ways to measure innovation performance such as the degree of novelty or innovation success (Mention, 2011). Several previous researches recommended not using a single measurement for innovation performance (Henard and Szymanski, 2001; Cheng and Huizingh, 2014). In line with Leiponen and Helfat (2010), our research is focused on two different assessments of innovation performance. Firstly, the innovation success is investigated to identify the factor of introduction a new product or new service by the firm (Baker and Sinkula, 2007). Secondly, the financial perspective is considered, relying on the percentage of product sales revenues from innovation and return on investment as declared by the respondents (Im and Workman, 2004).

Innovation activities have been seen as the key driver of enhanced business competitiveness as suggested by many different studies. In the last ten years, an increasing number of researchers have explored the impact of innovation on company performance (Freel, 2000; Rochina-Barrachina et al., 2010; Parida et al., 2012; Garcia Martinez et al., 2014) and identified innovation as the main driver for companies to thrive, prosper, grow, and sustain profitability (Drucker, 1988). Indeed, successful innovation should create value in link with the sales growth, while process innovations have been linked to productivity (Cainelli et al., 2006; Avlonitis and Salavou, 2007). Innovation is often connected with improved business performance in terms of company growth, profitability and productivity (Heunks, 1998, Tidd, 2001). Generally to push 
innovation activities, firms have been determinate a set of objectives to reach usually constraint by the group appurtenance and by the resources available (Mairesse and Mohnen, 2010). Prior studies have demonstrated the utility for the firms to identify objectives and to reach them to increase their propensity to innovate (Galia et al., 2013; Pavitt, 1984). This leads us to formulate the following hypotheses:

Hypothesis 1a The higher is the number of objectives pursued by the firm, the greater is the impact of breadth on the propensity to innovate.

Hypothesis $1 \mathrm{~b}$ The higher is the number of objectives pursued by the firm, the greater is the impact of breadth on the percentage of product sales revenues from innovation.

However, although many companies have placed innovation activities at the heart of their operations, internal innovation capabilities are very limited and fail to benefit or sustain a competitive advantage and the development of new products. Although allocating appropriate resources and company capabilities are a necessity, yet it is not sufficient for realising innovation. Strategic choices and initiatives need to be follow suit (DeSarbo et al., 2006). To mitigate the risks, firms try not to innovate alone and rely on external cooperation. The positive impact on performance to innovate of this practice has been demonstrated in prior research (van Beers and Zand, 2014). Since innovation became one of the main tools to enhance business performance via new products and services, more and more companies try to further improve their innovation performance through collaboration with external partners, which takes us away from traditional innovation (closed innovation) to a new innovation paradigm: open innovation (Temel et al., 2013a).

Open innovation has become one of the main topics in the innovation management field. The main premise of open innovation is the exposure of the innovation process to external partners. The new innovation paradigm assumes that companies can and should combine internal ideas, external ideas and paths to market, as a company looks to advance their capabilities (Chesbrough, 2003). Open innovation is considered to be a major driver for companies wanting to enhance their business performance (Elmquist et al., 2009; Vanhaverbeke and van de Vrande, 2008). Based on these grounds, we formulate the following two hypotheses:

Hypothesis 2a The more firms rely on external cooperation, the greater is the impact of breadth on the propensity to innovate.

Hypothesis $2 \mathrm{~b}$ The more firms rely on external cooperation, the greater is the impact breadth on the percentage of product sales revenues from innovation.

\subsection{The specific setting of emerging countries and the influence of open innovation}

As a new paradigm for companies to manage their innovation activities, open innovation is dependent on viable external institutional conditions. Thus, there is a very strong link between national innovation systems and open innovation (Edquist, 1997; Lundvall, 2010). The success of the system depends on the joint and individual contributions of companies, universities, research centres, customers, competitors and government agencies to the creation, dissemination and usage of knowledge. Hence, the successful 
implementation of open innovation is highly dependent on well-organised national innovation systems.

Emerging economies have unique social-economic characteristics and regularly evolve in poorly developed national innovation systems. Previous research pointed out those companies in emerging economies such as Turkey use price as one of the tool for competition (Craig and Douglas, 1997; Temel et al., 2013a, 2013b). Despite that, innovation is also an important instrument for companies to confront the intensified competition on their markets i.e., by offering new or improved products on the market or the same products at a lower price or both. But in the domestic market, most of the consumers are not willing to pay significantly higher prices for the new products that come as a result of the innovation process (Pamukçu and Erdil, 2011) because of low consumer income (Batra, 1997). Therefore, in a highly competitive environment firms are struggling to maintain the cost of the innovation through different means. Thus, most of the companies in emerging economies are either imitators or adapters of technologies developed in advanced countries. This is because companies in these countries typically do not have access to the right technical skills and managerial knowledge while at the same time lacking, and limited financial sources as well as the necessary experience in innovation (Pengfei and Yisha, 2010). But, this is not the same for international companies that are locating in the emerging economies for production and export their goods and services to developed economies. Those well-known international companies locate in emerging economies such as Turkey for production they do innovate and they have markets at domestic and international level. However, it is difficult for local companies to achieve same results due to lack of reputation, finance and network (Lewin and Massini, 2003). With regards to collaboration for innovation in emerging economies, the main focus is still on the creation of cooperation between different departments within the same companies and only those few companies that have better capacity can cooperate with external partners (Dwairi et al., 2007).

In most of the emerging economies, companies are willing to work with external partners as long as there is mutual trust and benefit among them, which takes a long time to emerge (Salampasis et al., 2014). In addition, having had some bad experiences with heavy-handed bureaucratic processes and judiciary systems in those countries, companies are not willing to take the risk to work with external partners.

Universities in emerging economies are mainly teaching-intensive and although some universities have well established and advanced labs, they have not managed to set up a good system for joint projects between university and industry (Temel et al., 2013a, 2013b). According to Scholten and Temel (2014), in emerging countries, companies are willing to cooperate with universities as long as there are additional funds available; otherwise they are not likely to collaborate. Furthermore, there is a need to improve intellectual property rights management and enforcement systems in emerging economies to promote better cooperation (Wang and Zhou, 2012). Therefore, due to the limitations of knowledge and technology inflow and outflow in emerging economies, it might be difficult to carry out open innovation strategy in such countries. 


\section{Data and methods}

\subsection{Data and statistical inference}

The community innovation survey (henceforth, CIS) data allows researchers to instigate the sources and basic elements that describe innovation in manufacturing and service firms. The latter was long time considered to be less important for innovation studies as they are less $R \& D$ intensive. The service sector was believed to be a passive adopter of technology from other sectors or as a sector trying to use innovations developed within the manufacturing sector (Pavitt, 1984; Toivonen and Tuominen, 2009). CIS data also allows discussing direct implications of innovation by inquiring firms' innovativeness, their possible sources of information for their innovation activities and their intended goals of these innovation initiatives. Using this harmonised instrument for innovation, leads to the enhancement of the overall incisiveness and understanding of innovation in services and manufacturing sectors. CIS data therefore allows a better understanding of the similarities and the significant discrepancies between and across sectors.

The data used to analyse patterns of innovation in the Turkey manufacturing industry is a derivative and an amended version of the CIS. CIS collects data on innovation practices and is a reliable source of information on innovation activities in firms. The data collected are well-known to make available information on the innovativeness of enterprises according to the type and the activities sectors, but also to provide significant material on the different types of innovation including various aspects of the development of an innovation, such as the objectives, the sources of information, the public funding, the innovation expenditures etc. The amended version used for our data sample contains the same indicators, but misses the part on the detailed information of the firm. The reference period of the survey is 2006 to 2008. CIS, conducted in Turkey by the Turkish Statistical Institute (TSI), is administered to a sample of firms across the country. A representative sample of 5,834 enterprises was selected and surveyed by conducting face-to-face interviews with top level managers.

The survey itself covers many different aspects surrounding innovation, including the success of innovation. This is included in the questions dealing with the introduction of technological innovations and the changes in sales that were attributable to this new introduction. The structure of the CIS survey further investigates the innovation objectives, knowledge sources for innovation or other R\&D activities. The fact that the sources of innovation and the objectives for the firm's innovation activities are collected creates a unique dataset. Data from CIS are valuable because the objectives for innovation are available, something which is not always the case in other countries answering the CIS. In the paper by Leiponen and Helfat (2010), the R\&D survey data was combined with the CIS data survey. In our data sample, the data was already available, as it is part of the CIS questionnaire in the form it is administered in Turkey.

Data from the period 2006-2008 encompasses both the explanatory and the control variables in our research. It also includes the dependent variables, measuring the success of innovation and the share of revenues sales resulting from innovation. Minimal overlap between the dependent and the independent variables was achieved for the involved time periods, relaxing the simultaneity issues. Additionally, the short time lag between the objectives and sources of innovation and the outcomes of this innovation is appropriate for the types of innovations that tend to occur in the industries in our sample. In our data sample, the objectives and source of knowledge are correlated. A focus on the external 
source of co-operation has been explored on our paper. Previous research had shown a significant link between the innovation success and external co-operation. Innovation success could have been affected by the possible correlations between firm characteristics and innovation objectives and external co-operation because of our cross-sectional data. To limit this risk in our analysis, variables that control firm characteristics of this type have been added in our model. Because the Turkish version of the CIS data does not contain the data on employment, education of the employees cannot be used as an additional control variable.

Specific attention was given to the controlling for $R \& D$ expenditures and innovation capability since this is expected to have a large impact on the success of innovation, while further being correlated to the objectives of this innovation and its knowledge sources. Data on the objectives of innovation was unfortunately only available for one period of time; therefore it was not possible to use fixed-effects estimation for enhanced control on hidden firm heterogeneity.

\subsection{Methods}

The two dependent variables used in the model are the traditional innovation success and the percentage of product sales revenues from innovation. Innovation success is usually assessed by assess using a binary variable ( 0 or 1), which is identified as in the questionnaire an 'introduction of a new product' during the period 2006-2008. When the firm declares having a new good or a new service, the dependent variable in the entire model is equal to 1 , otherwise 0 . In our particular context, the model chosen to explore the dependent variable is a probit maximum likelihood maximum estimator. This type of model is often used to highlight the influence of external factor on propensity to innovate such as the knowledge management (Mangiarotti, 2012; Mangiarotti and Mention, 2014) or external cooperation (Janeiro et al., 2013; Rouvinen, 2002). At least $26 \%$ of firms declare having introduced a new product during the reference period. This percentage is very low compared to the EU-27 member states (excluding Greece), where an average of $51.6 \%$ of the firms declared having introduced an innovation in 2008 (EUROSTAT, 2012). However, this percentage of innovative firms is roughly similar to Eastern countries of European Union as Poland with $24.8 \%$ or Slovak Republic with $22.9 \%$ of innovative firms for the year 2004. Nevertheless, this only variable does not allow profiling the innovative firms. To complete this first step, the second dependent variable used is measured as the percentage of total turnover from product innovation that is new to the firm (Cassiman and Veugelers, 2006). This second regression will complete the first model. Given the specificity of the dependent variable, this second model is assessed using Tobit maximum likelihood estimation. The parameters of interest can be obtained by maximum likelihood estimation of a Tobit that accounts for censoring in innovative performance (Mohnen and Röller, 2005; Mothe and Thi, 2010). In our sample, this percentage is around $13.2 \%$. 
Table 1 Descriptive statistics $(\mathrm{N}=5834)$

\begin{tabular}{lcccc}
\hline Variable & Mean & Std error & Minimum & Maximum \\
\hline Employees & 247.50 & $1,073.39$ & 10 & 33,549 \\
Log employee & 4.17 & 1.44 & 2.30 & 10.42 \\
Business group $(0,1)$ & 0.17 & 0.37 & 0 & 1 \\
\% of the capital share of your & 6.24 & 22.50 & 0 & 100 \\
company by foreigner & & & & \\
Innovation success & 0.26 & 0.44 & 0 & 1 \\
Percent of product sales & 13.17 & 29.35 & 0 & 100 \\
revenues from innovation & & & & 8 \\
Objectives & 1.60 & 2.53 & 0 & 7 \\
Cooperation & 0.34 & 1.31 & 0 & \\
\hline
\end{tabular}

Table 2 Innovation objectives and cooperation

\begin{tabular}{lc}
\hline Objectives & Percent in our sample \\
\hline Increased range of goods or services & $26.97 \%$ \\
Replace outdated products or processes & $20.25 \%$ \\
Enter new markets or increase market share & $22.21 \%$ \\
Improve flexibility for producing goods/services & $28.52 \%$ \\
Increased capacity of production or service provision & $21.27 \%$ \\
Reduced labour costs per unit output & $23.50 \%$ \\
Reduced materials and energy per unit output & $18.74 \%$ \\
Met regulatory requirements & $17.43 \%$ \\
\hline Cooperation & Percent in our sample \\
\hline Other enterprises within your enterprise group & $6.65 \%$ \\
Suppliers of equipment, materials, components, or software & $8.66 \%$ \\
Clients or customers & $7.54 \%$ \\
Competitors or other enterprises in your sector & $4.62 \%$ \\
Consultants, commercial labs, or private R\&D institutes & $5.90 \%$ \\
Universities or other higher education institutions & $4.18 \%$ \\
Government or public research institutes & $3.58 \%$ \\
\hline
\end{tabular}

According previous results on the dataset, two different breadths of innovation had been identified of innovation objectives and on the external co-operation. For the first breadth, a set of question in the CIS deals with the importance of ten objectives. The amended version harvested only eight objectives (presented in Table 2). The answer has been collected on three point Likert scale. Following the method developed by Cohen and Malerba (2001), the objectives have been treated without difference on the importance between them. Based on the value of the Likert scale, binary variables have been created using the approach of Leiponen and Helfat (2010). For the cooperation, a part of the survey is dedicated to the "active participation with other enterprises or non-commercial institutions on innovation activities" where both partners do not need to gain a commercial benefit. In this definition, pure contracting out of work has been excluded. 
Partners for innovation activities may be located inside the country or reside beyond boundaries, namely in other European countries, USA, China or India, and all other countries. Cooperation is first modelled as an aggregated variable taking the value of 1 if the firm cooperates, with any partner, located in any of the listed geographical areas. All the variable relative to the cooperation have been dichotomised to identify the use of cooperation by the firm (Mention et al., 2013).

The main difficulty of this kind of approach is how to determine the importance of the breadth. In their approach, Leiponen and Helfat (2010) have followed the literature on the breadth for external source of information (Mol and Birkinshaw, 2009; Laursen and Salter, 2006) which sums the binary variable to assess the influence and the importance of the breadth. They applied the methodology for the objectives. In our research, all the binary variables for the cooperation have been summed up to identify the practices of the firms.

Control variables have been added to the model to mitigate the external effects. The size (expressed in natural $\log$ ) and being part of group were used in all the models. The impact of the size of the firms on their propensity to innovate does not require any additional evidence (Vaona and Pianta, 2008). These two variables are often used in the case of analyses involving CIS data (Evangelista et al., 1997; Lhuillery and Pfister, 2009; Temel et al., 2013a). In our particular case of an emerging economy, a variable presenting the percentage of foreign capital shares. Previous studies, by scholars such as Wang and Kafouros (2009), have shown the influence of ownership. Dummy variables were also included to moderate the industrial effect in the model with all the data (results not shown).

\section{Results}

Table 3 presents a correlation matrix for the variables introduced in the different models. The correlations between the different variables of our model show a close link between the percentage of product sale and innovation success, $\rho=0.76$. The link is self-explanatory as firms cannot have an amount of revenues from innovation without the presence of innovation. The correlation between objectives and cooperation is high and positive $\rho=0.39$.

Table 3 Correlation coefficients $(\mathrm{N}=5$ 834)

\begin{tabular}{|c|c|c|c|c|c|c|}
\hline & 1 & 2 & 3 & 4 & 5 & 6 \\
\hline Log employee & 1 & & & & & \\
\hline Business group $(0,1)$ & $0.3352 *$ & 1 & & & & \\
\hline $\begin{array}{l}\% \text { of the capital share of your } \\
\text { company by foreigner }\end{array}$ & $0.2042 *$ & $0.3907^{*}$ & 1 & & & \\
\hline Innovation success & $0.1821 *$ & $0.1156^{*}$ & $0.0731^{*}$ & 1 & & \\
\hline $\begin{array}{l}\text { Percent of product sales } \\
\text { revenues from innovation }\end{array}$ & $0.0625^{*}$ & $0.0263^{*}$ & $0.0169 *$ & $0.7565^{*}$ & 1 & \\
\hline Objectives & $0.1937^{*}$ & $0.1078^{*}$ & $0.0632 *$ & $0.7568^{*}$ & $0.5852 *$ & 1 \\
\hline Cooperation & $0.2112 *$ & $0.1364 *$ & $0.0552 *$ & $0.3640 *$ & $0.2496^{*}$ & $0.3889 *$ \\
\hline
\end{tabular}

Note: ${ }^{*}$ Significance $<0.1 \%$. 
Table 4 Breadth of innovation objectives and co-operation $(\mathrm{N}=5$ 863)

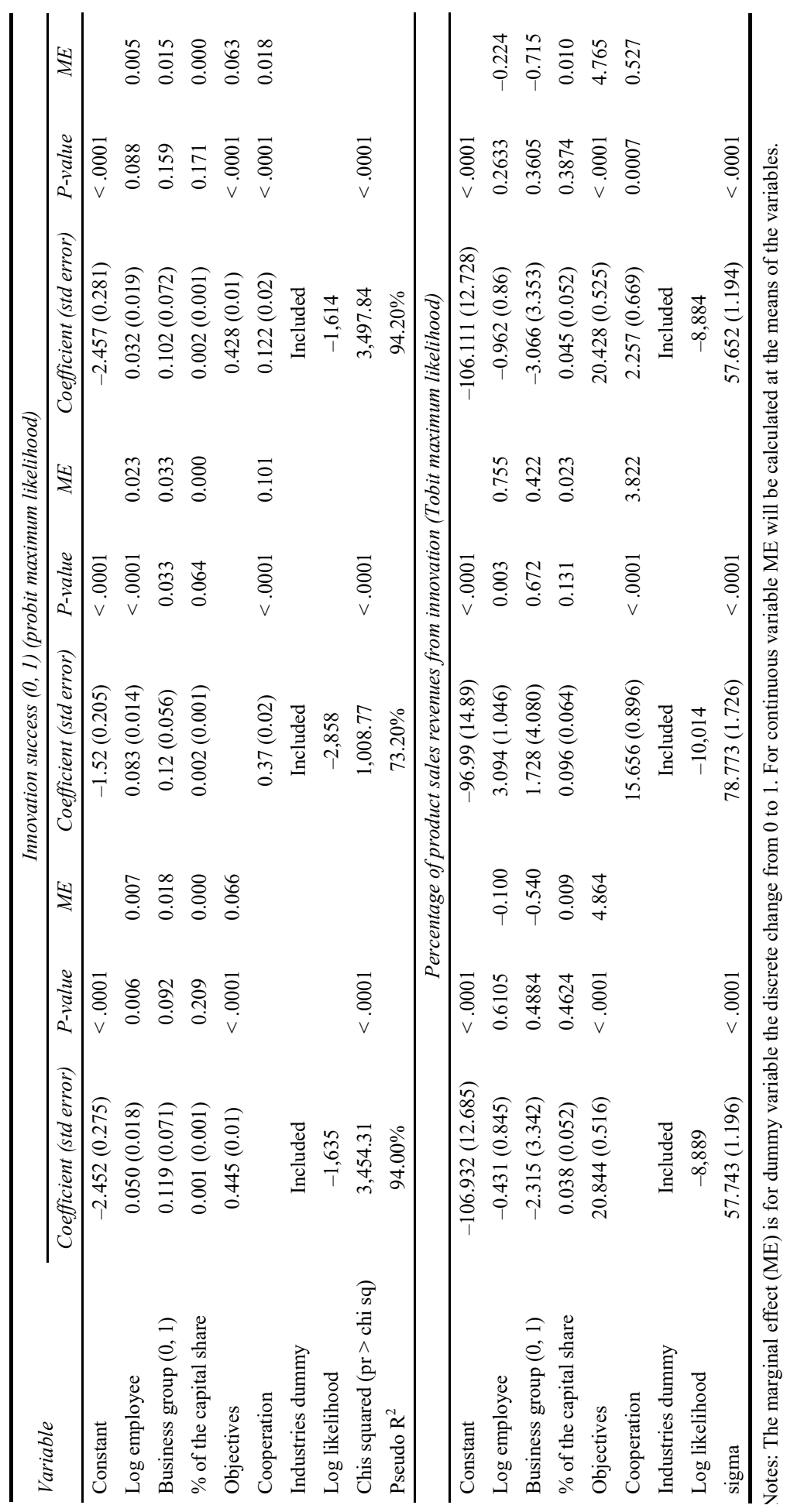


Table 5 Interaction of the breadth of innovation objectives and external co-operation $(\mathrm{N}=5,863)$

\begin{tabular}{|c|c|c|c|}
\hline \multirow[t]{2}{*}{ Variable } & \multicolumn{3}{|c|}{$\begin{array}{c}\text { Innovation success }(0,1) \text { (probit maximum } \\
\text { likelihood) }\end{array}$} \\
\hline & Coefficient (std error) & P-value & $M E$ \\
\hline Constant & $-2.474(0.28)$ & $<.0001$ & \\
\hline Log employee & $0.025(0.019)$ & 0.177 & 0.004 \\
\hline Business group $(0,1)$ & $0.094(0.073)$ & 0.195 & 0.014 \\
\hline$\%$ of the capital share of your company by foreigner & $0.002(0.001)$ & 0.152 & 0.000 \\
\hline Objectives & $0.441(0.01)$ & $<.0001$ & 0.0635 \\
\hline Cooperation & $0.421(0.055)$ & $<.0001$ & 0.061 \\
\hline Objectives $\times$ cooperation & $-0.062(0.01)$ & $<.0001$ & -0.009 \\
\hline Industries dummy & Included & & \\
\hline Log likelihood & $-1,593$ & & \\
\hline Chis squared ( $\mathrm{pr}>$ chi sq) & $3,539.47$ & $<.0001$ & \\
\hline \multirow[t]{2}{*}{ Pseudo $\mathrm{R}^{2}$} & $94.10 \%$ & & \\
\hline & \multicolumn{3}{|c|}{$\begin{array}{l}\text { Percent of product sales revenues from } \\
\text { innovation (Tobit maximum likelihood) }\end{array}$} \\
\hline Constant & $-108.696(12.865)$ & $<.0001$ & \\
\hline Log employee & $-1.328(0.859)$ & 0.122 & -0.311 \\
\hline Business group $(0,1)$ & $-3.388(3.345)$ & 0.311 & -0.793 \\
\hline$\%$ of the capital share of your company by foreigner & $0.045(0.052)$ & 0.384 & 0.011 \\
\hline Objectives & $21.178(0.542)$ & $<.0001$ & 4.954 \\
\hline Cooperation & $20.331(2.093)$ & $<.0001$ & 4.756 \\
\hline Objectives $\times$ cooperation & $-3.328(0.366)$ & $<.0001$ & -0.778 \\
\hline Industries dummy & Included & & \\
\hline Log likelihood & $-8,842$ & & \\
\hline Sigma & $57.176(1.182)$ & $<.0001$ & \\
\hline
\end{tabular}

Notes: The ME is for dummy variable the discrete change from 0 to 1.

For continuous variable ME will be calculated at the means of the variables.

The regressions presented in Table 4 investigated the link between the breadth of objectives and cooperation and innovation success. All the probit regressions demonstrate a pseudo $\mathrm{R}^{2}$ greater than $70 \%$, which confirms a good adequacy of our model. The results for both types of breadth are significant at a $1 \%$ level. Not surprisingly, the coefficients are positive, which means that the higher is the number of objectives the firm pursues and the higher is the number of partners it has, the higher is its propensity to innovate. This effect is more noticeable on the innovation success when the objectives and cooperation are entered separately in the regression. The last regression may indicate a stronger influence of the objectives rather than of cooperation. Again in the Tobit regression, the objectives and the cooperation are significant at the threshold of $1 \%$. The same trend might be observed on the importance of objectives and cooperation, as in the probit regressions. Indeed, in our sample, the probability to innovate is more determined by the objectives than by the cooperation patterns. To ensure the quality of our results and to 
explore more deeply these results, a sensitive analysis has been conducted regarding the impact of the objectives and the cooperation. The interaction effects have been investigated in Table 5. The results remain significant. A negative interaction has been found for the marginal effect (ME) of the objective and the cooperation. The high correlation between both variables may however induce multicollinearity.

Table 6 investigates the optimum level of breadth to obtain a higher innovation success or a higher percentage of product sales revenues from innovation. To conduct this research, dummy variable have been generated on the number of objectives or cooperation used by the firm ( 0 or 1$)$. For example, when the firm declares having two objectives, the variable 'two' introduced in the model is equal to 1 , otherwise 0 . For the objectives, a higher number of objectives provided a higher probability of innovation success and the same trend might be observed for the percentage of product sales revenues sales from innovation (consistent with Hypotheses 1a and 1b). In the case of cooperation, a peak is observed when firms are involved in cooperation with three different partners, and this number of partnership seems to be the most valuable to the firm. Indeed, the MEs of the probit regression on innovation increase until three partners are reached and then slightly decrease with four types of cooperation. Having six types of cooperation obtained the highest ME on the innovation success. This fact does not allow rejecting Hypothesis 2a. Nevertheless in the Tobit regression, three cooperation types had the highest $\mathrm{ME}$ on the percentage of product sales revenues (which is against our expectations as formulated in the Hypothesis 2b). We also find generally increasing returns up to a relatively large number of objectives and cooperation, providing support for the benefits of breadth.

Table 6 Diminishing returns to innovation objectives $(\mathrm{N}=5863)$

\begin{tabular}{|c|c|c|c|c|c|c|}
\hline \multirow[t]{2}{*}{ Variable } & \multicolumn{3}{|c|}{$\begin{array}{l}\text { Innovation success }(0,1) \\
\text { (probit maximum likelihood) }\end{array}$} & \multicolumn{3}{|c|}{$\begin{array}{l}\text { Percent of product sales } \\
\text { revenues from innovation } \\
\text { (tobit maximum likelihood) }\end{array}$} \\
\hline & $\begin{array}{l}\text { Coefficient } \\
\text { (std error) }\end{array}$ & P-value & $M E$ & $\begin{array}{l}\text { Coefficient } \\
\text { (std error) }\end{array}$ & P-value & $M E$ \\
\hline Constant & $-2.731(0.282)$ & $<.0001$ & & $-118.6(12.945)$ & $<.0001$ & \\
\hline Log employee & $0.018(0.02)$ & 0.3567 & 0.002 & $-2.263(0.844)$ & 0.0073 & -0.547 \\
\hline Business group $(0,1)$ & $0.12(0.077)$ & 0.119 & 0.015 & $-2.585(3.31)$ & 0.4349 & -0.625 \\
\hline $\begin{array}{l}\% \text { of the capital share } \\
\text { of your company by } \\
\text { foreigner }\end{array}$ & $0.001(0.001)$ & 0.3138 & 0.000 & $0.03(0.051)$ & 0.5578 & 0.007 \\
\hline \multicolumn{7}{|l|}{ Objectives } \\
\hline 1 & $2.238(0.132)$ & $<.0001$ & 0.288 & $109.879(6.508)$ & $<.0001$ & 26.565 \\
\hline 2 & $2.378(0.116)$ & $<.0001$ & 0.306 & $124.223(5.64)$ & $<.0001$ & 30.033 \\
\hline 3 & $2.465(0.103)$ & $<.0001$ & 0.317 & $130.234(5.058)$ & $<.0001$ & 31.486 \\
\hline 4 & $2.562(0.096)$ & $<.0001$ & 0.330 & $129.868(4.749)$ & $<.0001$ & 31.398 \\
\hline 5 & $2.839(0.095)$ & $<.0001$ & 0.366 & $135.259(4.536)$ & $<.0001$ & 32.701 \\
\hline 6 & $2.878(0.089)$ & $<.0001$ & 0.371 & $139.527(4.312)$ & $<.0001$ & 33.733 \\
\hline 7 & $2.956(0.082)$ & $<.0001$ & 0.381 & $144.865(4.089)$ & $<.0001$ & 35.023 \\
\hline
\end{tabular}

Notes: The ME is for dummy variable the discrete change from 0 to 1 .

For continuous variable ME will be calculated at the means of the variables. 
Table 6 Diminishing returns to innovation objectives $(\mathrm{N}=5863)$ (continued)

\begin{tabular}{|c|c|c|c|c|c|c|}
\hline \multirow{2}{*}{ Variable } & \multicolumn{3}{|c|}{$\begin{array}{l}\text { Innovation success }(0,1) \\
\text { (probit maximum likelihood) }\end{array}$} & \multicolumn{3}{|c|}{$\begin{array}{l}\text { Percent of product sales } \\
\text { revenues from innovation } \\
\text { (tobit maximum likelihood) }\end{array}$} \\
\hline & $\begin{array}{l}\text { Coefficient } \\
\text { (std error) }\end{array}$ & P-value & $M E$ & $\begin{array}{l}\text { Coefficient } \\
\text { (std error) }\end{array}$ & P-value & $M E$ \\
\hline Industries dummy & Included & & & Included & & \\
\hline Log likelihood & $-1,388$ & & & -8566 & & \\
\hline $\begin{array}{l}\text { Chis squared } \\
(\mathrm{pr}>\text { chi sq) }\end{array}$ & $3,948.68$ & $<.0001$ & & & & \\
\hline Pseudo $\mathrm{R}^{2}$ & $94.00 \%$ & & & & & \\
\hline Sigma & & & & $54.017(1.098)$ & $<.0001$ & \\
\hline Constant & $-1.52(0.205)$ & $<.0001$ & & $-96.595(14.88)$ & $<.0001$ & \\
\hline Log employee & $0.077(0.015)$ & $<.0001$ & 0.021 & $2.628(1.043)$ & 0.0117 & 0.641 \\
\hline Business group $(0,1)$ & $0.106(0.057)$ & 0.0639 & 0.028 & $0.405(4.083)$ & 0.9211 & 0.099 \\
\hline $\begin{array}{l}\% \text { of the capital share } \\
\text { of your company by } \\
\text { foreigner }\end{array}$ & $0.001(0.001)$ & 0.0638 & 0.000 & $0.094(0.063)$ & 0.1391 & 0.023 \\
\hline \multicolumn{7}{|l|}{ Cooperation } \\
\hline 1 & $1.237(0.153)$ & $<.0001$ & 0.333 & $71.755(9.69)$ & $<.0001$ & 17.496 \\
\hline 2 & $1.184(0.168)$ & $<.0001$ & 0.318 & $63.637(10.507)$ & $<.0001$ & 15.517 \\
\hline 3 & $2.004(0.21)$ & $<.0001$ & 0.539 & 93.094 (9.693) & $<.0001$ & 22.699 \\
\hline 4 & $1.698(0.192)$ & $<.0001$ & 0.457 & $80.123(10.437)$ & $<.0001$ & 19.537 \\
\hline 5 & $1.871(0.252)$ & $<.0001$ & 0.503 & $82.023(11.767)$ & $<.0001$ & 20.000 \\
\hline 6 & $2.236(0.369)$ & $<.0001$ & 0.601 & $85.343(14.368)$ & $<.0001$ & 20.809 \\
\hline 7 & $1.937(0.152)$ & $<.0001$ & 0.521 & $91.602(7.494)$ & $<.0001$ & 22.335 \\
\hline Industries dummy & Included & & & Included & & \\
\hline Log likelihood & -2817 & & & $-9,977$ & & \\
\hline $\begin{array}{l}\text { Chis squared } \\
(\mathrm{pr}>\text { chi sq) }\end{array}$ & $1,090.18$ & $<.0001$ & & & & \\
\hline Pseudo $\mathrm{R}^{2}$ & $73.70 \%$ & & & & & \\
\hline Sigma & & & & $78.091(1.708)$ & $<.0001$ & \\
\hline
\end{tabular}

Notes: The ME is for dummy variable the discrete change from 0 to 1 .

For continuous variable ME will be calculated at the means of the variables.

\section{Discussion and implications}

This empirical study aims to investigate the relationship between the breadth of objectives, the breadth of cooperation and innovation in the particular case of Turkey. This study contributes to the literature on the innovation process in emerging economies and extends the analyses using the CIS data. 
According to our findings, firms which pursue a higher number of objectives in relation to innovation face a higher propensity to innovate. This could lead to the conclusion that all contextual (i.e., regulation) and internal factors (quest for efficiency, effectiveness, new market positioning) have a strong influence on innovation success.

In addition, access to governmental funding also requires companies to set themselves a variety of goals, which may influence their behaviour when defining their strategies.

Quite logically, when the number of objectives is important, the financial performance of the innovation process is also higher, suggesting that there is a strong association between the strategies pursued by the firms (through their implementation and the achievement of those objectives), the innovation success and the financial performance from novelties, measured as the percentage of sales revenues from new products.

The effect is stronger when the number of objectives is higher, as the coefficients show. Regarding cooperation practices, conclusions are more mixed, as involving three partners in the innovation process seems to lead to higher performance in terms of innovative sales revenues while results are slightly more inconclusive regarding the optimum level of cooperation to ensure innovation success. A plausible explanation for this finding is that collaboration in precompetitive stage is not widespread among Turkish firms and the ecosystem is not mature yet. Therefore, companies tend to collaborate with a limited number of other stakeholders, and predominantly with suppliers, customers, parent/sister companies, Cooperation with competitors and universities has been demonstrated not to lead to immediate profits (Temel et al., 2013b) and is not a common practice in this specific setting.

\section{Limitations and recommendations for future research}

Understanding of the impact of external cooperation, and the optimal number of partners, on innovation performance requires several caveats. First, the peculiarities of our sample (emerging economy) do not allow for generalisability across all economies. Indeed, our data are only representative for one wave of the CIS data in Turkey. The results are not generalisable to e.g., western countries or to other emerging economies. Moreover, the results need to be deeply explored in further research. All objectives do not seem to have the same effect on the propensity to innovate and a detailed study should identify the best objective to have to maximise the success and the product sales revenues from innovation. Indeed, the cooperation should be studied according to both the type of partner (i.e., market, science, governmental bodies) and the geographical partnership such as the national or the international level. This analysis on the geographic distinctions would provide interesting results in terms of recommendations for future forms of cooperation. A specific focus on a particular sector of the economy such as the retail manufacturing, one of the pillars of the Turkish economy should be very valuable. Future work should highlight the specificities of this sector and address recommendations to the sector. 


\section{References}

Alcalde, H. and Guerrero, M. (2016) 'Open business models in entrepreneurial stages: evidence from young Spanish firms during expansionary and recessionary periods', International Entrepreneurship and Management Journal, Vol. 12, No. 2, pp.393-413.

Amara, N., Landry, R. and Doloreux, D. (2009) 'Patterns of innovation in knowledge-intensive business services', The Service Industries Journal, Vol. 29, No. 2, pp.407-430 [online] http://www.tandfonline.com/toc/fsij20/29/4.

Avlonitis, G.J. and Salavou, H.E. (2007) 'Entrepreneurial orientation of SMEs, product innovativeness, and performance', Journal of Business Research, Vol. 60, No. 5, pp.566-575.

Baker, W.E. and Sinkula, J.M. (2007) 'Does market orientation facilitate balanced innovation programs? An organizational learning perspective', Journal of Product Innovation Management, Vol. 24, No. 4, pp.316-334.

Bamford, J.D., Gomes-Casseres, B. and Forbes, L.L.C. (2003) Mastering Alliance Strategy: A Comprehensive Guide to Design, Management, and Organization, John Wiley \& Sons, Jossey-Bass A wiley Imprint 989 Market Street, San Francisco, CA 94103-1741.

Batra, R. (1997) 'Marketing issues and challenges in transitional economies', Journal of International Marketing, Vol. 5, No. 4, pp.95-114, Springer, USA.

Becker, W. and Dietz, J. (2004) 'R\&D cooperation and innovation activities of firms - evidence for the German manufacturing industry', Research Policy, Vol. 33, No. 2, pp.209-223.

Cainelli, G., Evangelista, R. and Savona, M. (2006) 'Innovation and economic performance in services: a firm-level analysis', Cambridge Journal of Economics, Vol. 30, No. 3, pp.435-458.

Caloghirou, Y., Kastelli, I. and Tsakanikas, A. (2004) 'Internal capabilities and external knowledge sources: complements or substitutes for innovative performance?', Technovation, Vol. 24, No. 1, pp.29-39.

Cassiman, B. and Veugelers, R. (2006) 'In search of complementarity in innovation strategy: internal R\&D and external knowledge acquisition', Management science, Vol. 52, No. 1, pp.68-82.

Cheng, C.C.J. and Huizingh, E.K.R.E. (2014) 'When is open innovation beneficial? The role of strategic orientation', Journal of Product Innovation Management, Vol. 31, No. 6, pp.1235-1253.

Chesbrough, H. (2003) 'Open innovation and the business model: implications for industrial research', Presentation to Joint OECD/Dutch Ministry of Economic Affairs Conference on 'Globalization and Open Innovation', pp.119-148.

Cohen, W.M. and Levinthal, D.A. (1990) 'Absorptive capacity: a new perspective on learning and innovation', Administrative Science Quarterly, Vol. 35, No. 1, pp.128-152.

Cohen, W.M. and Malerba, F. (2001) 'Is the tendency to variation a chief cause of progress?', Industrial and Corporate Change, Vol. 10, pp.587-608.

Cooper, R.G. and Edgett, S.J. (2003) 'Overcoming the crunch in resources for new product development', Research-Technology Management, Vol. 46, No. 3, pp.48-58.

Craig, C.S. and Douglas, S.P. (1997) 'Managing the transnational value chain: strategies for firms from emerging markets', Journal of International Marketing, Vol. 5, No. 3, pp.71-84.

Damanpour, F., Walker, R.M. and Avellaneda, C.N. (2009) 'Combinative effects of innovation types and organizational performance: a longitudinal study of service organizations', Journal of Management Studies, Vol. 46, No. 4, pp.650-675.

De Jong, J.P.J. and Marsili, O. (2006) 'The fruit flies of innovations: a taxonomy of innovative small firms', Research Policy, Vol. 35, No. 2, pp.213-229.

Desarbo, W.S., Di Benedetto, C.A., Jedidi, K. and Song, M. (2006) 'Identifying sources of heterogeneity for empirically deriving strategic types: a constrained finite-mixture structuralequation methodology', Management Science, Vol. 52, No. 6, pp.909-924.

Drucker, P.F. (1988) 'The coming of the new organization', Harvard Business Review, January-February. 
Dwairi, M., Bhuian, S.N. and Jurkus, A. (2007) 'Revisiting the pioneering market orientation model in an emerging economy', European Journal of Marketing, Vol. 41, Nos. 7/8, pp.713-721.

Edquist, C. (1997) Systems of Innovation: Technologies, Institutions, and Organizations, Psychology Press, Routledge, ISBN: 1-85567-452-1.

Elmquist, M., Fredberg, T. and Ollila, S. (2009) 'Exploring the field of open innovation', European Journal of Innovation Management, Vol. 12, No. 3, pp.326-345.

Enkel, E. and Heil, S. (2014) 'Preparing for distant collaboration: antecedents to potential absorptive capacity in cross-industry innovation', Technovation, Vol. 34, No. 4, pp.242-260.

Evangelista, R., Perani, G., Rapiti, F. and Archibugi, D. (1997) 'Nature and impact of innovation in manufacturing industry: some evidence from the Italian innovation survey', Research Policy, Vol. 26, Nos. 4/5, pp.521-536.

Forsman, H. and Annala, U. (2011) 'Small enterprises as innovators: shift from a low performer to a high performer', International Journal of Technology Management, Vol. 56, Nos. 3/4, pp.154-171.

Forsman, H. and Temel, S. (2011) 'Innovation and business performance in small enterprises: an enterprise-level analysis', International Journal of Innovation Management, Vol. 15, No. 3, pp.641-665.

Freel, M.S. (2000) 'Do small innovating firms outperform non-innovators?', Small Business Economics, Vol. 14, No. 3, pp.195-210.

Galia, F., Ingham, M. and Pekovic, S. (2013) 'Environmental benefits of forms of innovations in French manufacturing firms', 35th DRUID Celebration Conference.

Garcia Martinez, M., Lazzarotti, V., Manzini, R. and Sánchez García, M. (2014) 'Open innovation strategies in the food and drink industry: determinants and impact on innovation performance', International Journal of Technology Management, Vol. 66, Nos. 2/3, pp.212-242.

George, G., Zahra, S.A. and Wood Jr., D.R. (2002) 'The effects of business-university alliances on innovative output and financial performance: a study of publicly traded biotechnology companies', Journal of Business Venturing, Vol. 17, No. 6, pp.577-609.

Griliches, Z. (1994) 'Productivity, R\&D, and the data constraint', The American Economic Review, Vol. 84, No. 1, pp.1-23.

Helfat, C.E. (1994) Evolutionary Trajectories in Petroleum Firm R\&D. Management Coevolutionary Problem Solving, Working Paper No. 94-06.

Henard, D.H. and Szymanski, D.M. (2001) 'Why some new products are more successful than others', Journal of Marketing Research, Vol. 38, No. 3, pp.362-375.

Heunks, F.J. (1998) 'Innovation, creativity and success', Small Business Economics, Vol. 10, No. 3, pp.263-272.

Im, S. and Workman, J.P. (2004) 'Market orientation, creativity, and new product performance in high-technology firms', Journal of Marketing, Vol. 68, No. 2, pp.114-132.

Janeiro, P., Proença, I. and Gonçalves, V.D.C. (2013) 'Open innovation: factors explaining universities as service firm innovation sources', Marketing Communications and Consumer Behahvior, Vol. 66, No. 10, pp.2017-2023.

Katila, R. and Ahuja, G. (2002) 'Something old, something new: a longitudinal study of search behavior and new product introduction', Academy of Management Journal, Vol. 45, No. 6, pp.1183-1194.

Kaufmann, A. and Tödtling, F. (2001) 'Science-industry interaction in the process of innovation: the importance of boundary-crossing between systems', Research Policy, Vol. 30, No. 5, pp.791-804.

Klevorick, A.K., Levin, R.C., Nelson, R.R. and Winter, S.G. (1995) 'On the sources and significance of interindustry differences in technological opportunities', Research Policy, Vol. 24, No. 2, pp.185-205. 
Laursen, K. and Salter, A. (2006) 'Open for innovation: the role of openness in explaining innovation performance among U.K. manufacturing firms', Strategic Management Journal, Vol. 27, No. 2, pp.131-150.

Leiponen, A. and Helfat, C.E. (2010) 'Innovation objectives, knowledge sources, and the benefits of breadth', Strategic Management Journal, Vol. 31, No. 2, pp.224-236.

Lewin, A.Y. and Massini, S. (2003) 'Knowledge creation and organizational capabilities of innovating and imitating firms', Organizations as Knowledge Systems, pp.209-237.

Lhuillery, S. and Pfister, E. (2009) 'R\&D cooperation and failures in innovation projects: empirical evidence from French CIS data', Research Policy, Vol. 38, No. 1, pp.45-57.

Löfsten, H. (2014) 'Information structures and business performance - implications for technologybased firm's innovation performance', Knowledge and Process Management, Vol. 21, No. 4, pp.246-259.

Lundvall, B-A. (2010) National Systems of Innovation: Toward a Theory of Innovation and Interactive Learning, Anthem Press, UK and USA.

Mairesse, J. and Mohnen, P. (2010) Using Innovations Surveys for Econometric Analysis, National Bureau of Economic Research.

Mangiarotti, G. (2012) 'Knowledge management practices and innovation propensity: a firm-level analysis for Luxembourg', International Journal of Technology Management, Vol. 58, Nos. 3-4, pp.261-283.

Mangiarotti, G. and Mention, A-L. (2014) 'Investigating firm-level effects of knowledge management strategies on innovation performance', International Journal of Innovation Management, Vol. 19, No. 1.

Mention, A-L. (2011) 'Co-operation and co-opetition as open innovation practices in the service sector: which influence on innovation novelty?', Technovation, Vol. 31, No. 1, pp.44-53.

Mention, A-L., Temel, S. and Torkkeli, M. (2013) 'Innovation and cooperation in emerging economies: two sides of the same coin?', International Conference on Innovation and Entrepreneurship, Amman, 4-5 March.

Mohnen, P. and Röller, L-H. (2005) 'Complementarities in innovation policy', European Economic Review, Vol. 49, No. 6, pp.1431-1450.

Mol, M.J. and Birkinshaw, J. (2009) 'The sources of management innovation: when firms introduce new management practices', Marketing Communications and Consumer Behahvior, Vol. 62, No. 12, pp.1269-1280.

Mothe, C. and Thi, T.U.N. (2010) 'The link between non-technological innovations and technological innovation', European Journal of Innovation Management, Vol. 13, No. 3, pp.313-332.

Pamukçu, M.T. and Erdil, E. (2011) Analyzing R\&D Activities of Foreign Enterprises in Emerging Economies, Lessons from Turkey, No. 1104, STPS Science and Technology Policy Studies Center, Middle East Technical University.

Parida, V., Westerberg, M. and Frishammar, J. (2012) 'Inbound open innovation activities in high-tech SMEs: the impact on innovation performance', Journal of Small Business Management, Vol. 50, No. 2, pp.283-309.

Pavitt, K. (1984) 'Sectoral patterns of technical change: towards a taxonomy and a theory', Research Policy, Vol. 13, No. 2, pp.343-373.

Pengfei, W. and Yisha, Z. (2010) 'The role of outbound-revealing open innovation: Theoretical extension and case study', in 2010 IEEE International Conference on Industrial Engineering and Engineering Management, December.

Porter, M.E. (1993) The Competitive Advantage of Nations, Harvard Business School Management Programs.

Rochina-Barrachina, M.E., Mañez, J.A. and Sanchis-Llopis, J.A. (2010) 'Process innovations and firm productivity growth', Small Business Economics, Vol. 34, No. 2, pp.147-166. 
Rouvinen, P. (2002) 'Characteristics of product and process innovators: some evidence from the Finnish innovation survey', Applied Economics Letters, Vol. 9, No. 9, pp.575-580.

Salampasis, D., Mention, A.L. and Torkkeli, M. (2014) Rust Embedded Open Innovation: Literature Review, Synthesis \& Research Propositions, Academy of Management Meeting. Philadelphia, USA.

Schilling, M.A. (2005) Strategic Management of Technological Innovation, Tata McGraw-Hill Education.

Scholten, V. and Temel, S. (2014) Global Innovation Science Handbook, Chapter 27 - Open Innovation, McGraw Hill Professional.

Schumpeter, J.A. (1934) The Theory of Economic Development: An Inquiry Into Profits, Capital, Credit, Interest, and the Business Cycle, Transaction Publishers, New Brunswick, USA; London, UK.

Teece, D.J., Pisano, G. and Shuen, A. (1997) 'Dynamic capabilities and strategic management', Strategic Management Journal, Vol. 18, No. 7, pp.509-533.

Temel, S., Mention, A.L. and Torkkeli, M. (2013a) 'The impact of cooperation on firms' innovation propensity in emerging economies', Journal of Technology Management \& Innovation, Vol. 8, No. 1, pp.54-64.

Temel, S., Scholten, V., Akdeniz, R.C., Fortuin, F. and Omta, O. (2013b) 'University-industry collaboration in Turkish SMEs: investigation of a U-shaped relationship', The International Journal of Entrepreneurship and Innovation, Vol. 14, No. 2, pp.103-115.

Tidd, J. (2001) 'Innovation management in context: environment, organization and performance', International Journal of Management Reviews, Vol. 3, No. 3, pp.169-183.

Toivonen, M. and Tuominen, T. (2009) 'Emergence of innovations in services', Service Industries Journal, Vol. 29, No. 7, pp.887-902.

Urban, G.L. and von Hippel, E. (1988) 'Lead user analyses for the development of new industrial products', Management Science, Vol. 34, No. 5, pp.569-582.

van Beers, C. and Zand, F. (2014) 'R\&D cooperation, partner diversity, and innovation performance: an empirical analysis', Journal of Product Innovation Management, Vol. 31, No. 2, pp.292-312.

Vanhaverbeke, W., Van de Vrande, V. and Chesbrough, H. (2008) 'Understanding the advantages of open innovation practices in corporate venturing in terms of real options', Creativity and Innovation Management, Vol. 17, No. 4, pp.251-258.

Vaona, A. and Pianta, M. (2008) 'Firm size and innovation in European manufacturing', Small Business Economics, Vol. 30, No. 3, pp.283-299.

von Hippel, E. (1988) The Sources of Innovation, Oxford University Press.

Wang, C. and Kafouros, M.I. (2009) 'What factors determine innovation performance in emerging economies? Evidence from China', International Business Review, Vol. 18, No. 6, pp.606-616.

Wang, P. and Zhou, Y. (2010) 'The role of outbound-revealing open innovation: theoretical extension and case study', IEEE International Conference on Industrial Engineering and Engineering Management (IEEM), Macao, pp.1890-1892.

Wang, Y. and Zhou, Z. (2012) 'Can open innovation approach be applied by latecomer firms in emerging countries?', Journal of Knowledge-Based Innovation in China, Vol. 4, No. 3, pp.163-173. 